\title{
RADIOLOGICAL SURVEYS OF WORKING QUARRYMEN AND QUARRYING COMMUNITIES IN CAERNARVONSHIRE
}

\author{
BY
}

\author{
T. FRANCIS JARMAN, J. GLYN JONES, J. H. PHILLIPS, and H. E. SEINGRY
}

From the Mass Radiography Service of the Welsh Regional Hospital Board and the Bangor Area Chest Clinic

(RECEIVED FOR PUBLICATION JANUARY, 1957)

Interest in the possible occupational lung diseases associated with slate-quarrying appears to date from the Registrar-General's Decennial Supplement, 1921, on Occupational Mortality (Registrar-General, 1927). Britten's review (Britten, 1928) showed that slate-masons and slate-workers had a significantly raised mortality from respiratory tuberculosis although it was much lower than that of tin- and copper-miners. At roughly the same time, Wade (1927) called attention to the excessive mortality from tuberculosis of the slate-workers in the Gwyrfai rural district in North Wales. Since then, most of the references in the international literature about this subject have referred to Wales, but descriptions of cases of pneumoconiosis in slatequarry workers have been published in other countries.

In France, Feil (1935) found relatively little pulmonary disease amongst slate-workers in Mayenne and Anjou. He attributed this to the low content of free silica $(7 \%)$ in the slates there. In Germany, Schairer (1940) described egg-shell calcification in two slate workers; Koelsch (1950) described the radiographic appearances, and Ceelen (1951) described one case. In Italy, Frola (1942) described the radiographic appearances in 34 stateworkers; and cases have been reported from the United States by Rogers (1932) and Mansur (1951).

In Wales, Wade's report was followed by the survey by Sutherland and Bryson (1930) who found clinical evidence of pulmonary fibrosis amongst 56 out of 120 slate-quarrymen. A few years later Chalke (1933) showed that $28 \%$ of the tuberculous males in the county of Caernarvon were slateworkers while this industry only absorbed $11 \%$ of the male population. Davies (1939) reported the results of examining 117 slate-workers chiefly from Merionethshire and, as a result, silicosis amongst slate-workers who worked underground was scheduled under the Workmen's Compensation Act. The section of the industry involving work above ground was not so scheduled. Davies (1942) reviewed silicosis amongst coal-miners and slateworkers in Wales. Later a committee of the Ministry of Works, under the chairmanship of Mr. F. Rees, reported on the Welsh slate industry (Ministry of Works, 1947). They considered that the fear of pneumoconiosis was preventing men entering the industry and recommended that the pneumoconiosis problem should be attacked at once.

The relative position of tuberculosis mortality in the Gwyrfai rural district has not improved since the time of Wade's original investigation. In 1928 the tuberculosis death rate was 285 per 100,000 persons compared with a figure of 96 for England and Wales. In 1951 the figures were 110 and 31 respectively.

In 1952 there was therefore evidence that pneumoconiosis - probably silicosis - was prevalent amongst slate-workers in North Wales, and that the tuberculosis death rate in the slate-quarrying areas was abnormally high. For these reasons, the Gwyrfai Rural District Council asked the Welsh Board of Health for an investigation, and as a result a survey was carried out by the Mass Radiography Service of the Welsh Regional Hospital Board in 1952-53, which is the subject of this paper.

\section{OBJECTIVES OF MASS RADIOGRAPHY SURVEY 1952-53}

The objectives of the survey were:-

(a) To ascertain the prevalence of pneumoconiosis amongst the slate-quarry workers; $(b)$ to ascertain the prevalence of active pulmonary tuberculosis amongst quarry workers; $(c)$ to determine whether any important relationship exists between $(a)$ and $(b)$; (d) to ascertain the prevalence of pulmonary tuberculosis amongst quarry and ex-quarry workers, living in "quarrying" communities; and $(e)$ to ascertain the prevalence of pulmonary tuberculosis amongst workers not concerned with quarrying in the male population of the quarrying towns and to 
compare this with the prevalence amongst quarry workers and ex-quarry workers.

\section{PART I: SURVEY OF WORKING QUARRYMEN \\ Extent of the Survey}

In order to achieve these objectives the aim was to radiograph as near $100 \%$ of the quarry workers at their place of work as possible. To radiograph ex-quarrymen, quarrymen not well enough to work, and males not engaged in quarrying it was necessary to carry out surveys of the "total community" type (Cochrane, Cox, and Jarman, 1952) in a limited number of the quarrying towns in the district. These surveys, which were carried out from November, 1953, to February, 1954, became an integral part of the work and are described in Part II of this paper.

\section{Planning and Propaganda}

The first stage in the survey was to radiograph the working quarrymen. The report of the Ministry of Works (1947) shows that slate quarrying is the main industry in this area of North Wales, and there are few opportunities of employment in other industries. This naturally renders the men more than ordinarily sensitive to any procedure which might appear as a threat to their occupational security. It was emphasized both from the management and trade union that it would be difficult to obtain a $100 \%$ response from the quarry workers, who are traditionally conservative in their outlook. It was therefore essential to obtain the fullest cooperation from both management and workers of the five slate quarries concerned. Joint consultations were arranged between the Welsh Sectional Industrial Council for the Slate Quarrying Industry (which includes representatives of workers and management), the chest physician, the Mass Radiography Service, and representatives from other interested medical services, at which the objectives of the scheme were discussed. Talks in English and by one of us (J.G.J.) in Welsh about the scheme and its objectives were given at places of work and in the canteens. Articles appeared in the local press, in English and Welsh, and an "on-the-spot" broadcast was radiated from the Welsh Region of the B.B.C. One of the most important measures which contributed to the success of the survey was, however, the personal canvassing of workers who had failed, without such persuasion, to attend. The mass radiography unit was taken to the place of work in the quarries and was moved from one "level" to another in order that the workers would not have to walk far from their place of work to be radiographed. The highest level at which the unit worked was in the Dinorwic quarry opposite Snowdon at a height of 2,000 feet above sea-level.

\section{Choice of Film}

It was recognized that in a radiological survey to ascertain the prevalence of pneumoconiosis fullsized films should be used. Unfortunately, an acute shortage of such films existed at the time of the survey, and a $70 \mathrm{~mm}$. " odelca" mirror camera attachment with a Watson 4-valve mobile unit was therefore used.

\section{Reading of the Films}

It has been shown that considerable error can arise in the reading of miniature and even full-sized radiographs when these are interpreted by a single reader. The films were, therefore, read by three of us independently; differences were resolved by discussion and agreement between the three readers in conference.

\section{Categories of Pneumoconiosis}

The classification of pneumoconiosis cases was carried out in accordance with the categories formulated by Fletcher, Mann, Davies, Cochrane, Gilson, and Hugh-Jones (1949) and accepted internationally after the I.L.O. conference on pneumoconiosis at Sydney in 1950 (Cochrane, Davies, and Fletcher, 1951). This classification is purely radiological and is not concerned with disability.

\section{Disposal of Cases}

All cases in which pulmonary tuberculosis or new growth was suspected by one or more of the three readers (with or without the presence of pneumoconiosis) were given appointments for an interview with one of us (H.E.S.) at the quarries, and were referred to the chest physician (J.G.J.), through their general practitioners, for further investigation. All cases of pneumoconiosis with massive fibrosis were considered as suspect cases of active pulmonary tuberculosis for this purpose. Appointments were also offered to all cases of pneumoconiosis of category 2 and upwards. At these interviews laryngeal swabs and/or sputum specimens were taken from those patients who were willing to cooperate in order to attempt an assessment of hidden tuberculous infectivity.

Cases of suspected pulmonary tuberculosis sent to the chest clinic were classified as "active" or "active and infectious" on the basis of bacteriological findings and radiological changes up to January 1,1955 . This was in accordance with the normal chest clinic practice, and cases were graded A or B, I, II, or III (Ministry of Health classification, Memorandum 37/T, Revised). 
The follow-up of cases referred to the chest physician was necessarily slow. Out of the 219 men referred to the chest clinic for observation and assessment, 27 failed to attend, and this, of course, represents a serious shortcoming of this work.

\section{Results}

Two thousand four hundred and thirty-two working quarrymen, $90 \%$ of the men employed, were radiographed. Table 1 shows the classification

TABLE 1

ANALYSIS OF CHEST FILMS OF WORKING QUARRYMEN

\begin{tabular}{|c|c|c|c|c|c|}
\hline \multirow[b]{2}{*}{$\begin{array}{l}\text { Category of } \\
\text { Pneumo- } \\
\text { coniosis }\end{array}$} & \multicolumn{3}{|c|}{ Other Complications } & \multirow[b]{2}{*}{ None } & \multirow[b]{2}{*}{ Total } \\
\hline & $\begin{array}{l}\text { Suspected } \\
\text { Pulmonary } \\
\text { Tuberculosis }\end{array}$ & $\begin{array}{c}\text { Suspected } \\
\text { New } \\
\text { Growth }\end{array}$ & $\begin{array}{c}\text { Other } \\
\text { Pulmonary } \\
\text { Abnor- } \\
\text { malities }\end{array}$ & & \\
\hline $\begin{array}{c}\text { Category } 0 \\
\text { Category } 1 \\
\text { Category } 2 \\
\text { Category } 3 \\
\text { Progressive } \\
\text { massive } \\
\text { fibrosis }\end{array}$ & $\begin{array}{r}30 \\
100 \\
53 \\
15\end{array}$ & $\begin{array}{l}2 \\
3 \\
\overline{1}\end{array}$ & $\frac{73}{1}$ & $\begin{array}{r}1,573 \\
448 \\
102 \\
16\end{array}$ & $\begin{array}{r}1,678 \\
551 \\
156 \\
32\end{array}$ \\
\hline Totals & 213 & 6 & 74 & 2,139 & 2,432 \\
\hline
\end{tabular}

of the films for pneumoconiosis, suspected pulmonary tuberculosis, suspected new growth, and other pulmonary abnormalities, and Table 2 the prevalence of pneumoconiosis by age.

TABLE 2

ANALYSIS OF CHEST FILMS OF WORKING QUARRYMEN BY AGE AND CATEGORY OF PNEUMOCONIOSIS

\begin{tabular}{|c|c|c|c|c|c|c|}
\hline \multirow{2}{*}{$\begin{array}{l}\text { Age } \\
\text { Group } \\
\text { (years) }\end{array}$} & \multicolumn{5}{|c|}{ Category of Pneumoconiosis } & \multirow{2}{*}{ Total } \\
\hline & 0 & 1 & 2 & 3 & P.M.F. & \\
\hline $15-24$ & $\begin{array}{c}280 \\
96.2 \%\end{array}$ & $\begin{array}{c}10 \\
3.4 \%\end{array}$ & $0.4 \%$ & - & - & 291 \\
\hline $25-34$ & $\begin{array}{l}374^{\circ} \\
87.4 \%\end{array}$ & $\begin{aligned} 53^{\circ} & \\
12 \cdot 4^{\circ} & \end{aligned}$ & $0.2 \%$ & - & - & 428 \\
\hline $35-44$ & $\begin{array}{r}0145^{\circ} \\
70.8 \%\end{array}$ & $137^{\circ}$ & $\begin{array}{r}26 \\
4.5 \%\end{array}$ & $\begin{array}{c}3 \\
0.5 \%\end{array}$ & $0.2 \%$ & 572 \\
\hline $45-54$ & $564^{\circ}$ & 205 & $6.2^{\circ}$ & $11^{\circ}$ & $0.8 \%$ & 627 \\
\hline $55-64$ & $\begin{array}{l}179 \\
49.6 \%\end{array}$ & $108^{\circ}$ & $\begin{array}{r}57^{\circ} \\
15.8 \%\end{array}$ & $13^{\circ}$ & 4. & 361 \\
\hline $65+$ & $\begin{array}{r}76 \% \\
49.7 \%\end{array}$ & $\begin{array}{l}38 \\
24.8 \%\end{array}$ & $\begin{array}{r}13.8 \% \\
29 \\
18.9 \%\end{array}$ & $\begin{array}{l}5.6 \% \\
3.3 \%\end{array}$ & $\begin{array}{l}1.1 \% \\
3.3 \%\end{array}$ & 153 \\
\hline Total: & $\begin{array}{l}1,678 \\
69.0 \%\end{array}$ & $\begin{array}{r}551 \\
22.7 \%\end{array}$ & $\begin{array}{l}156 \\
6.4 \%\end{array}$ & $\begin{array}{c}32 \\
1.3 \%\end{array}$ & $\begin{array}{c}15 \\
0.6 \%\end{array}$ & 2,432 \\
\hline
\end{tabular}

The 213 cases classified as " suspected pulmonary tuberculosis" and six cases of possible new growth were offered interviews. All attended with the unfortunate exception of eight cases of suspected pulmonary tuberculosis. For the purpose of statistical analysis these eight cases are included in those who failed to attend the clinic in Table 3.

Prevalence of Pulmonary Tuberculosis in Working Quarrymen.-Table 3 shows the final classification on January 1, 1955, of the 219 working quarrymen 3
TABLE 3

CLASSIFICATION OF 219 WORKING OUARRYMEN REFERRED TO CHEST CLINIC

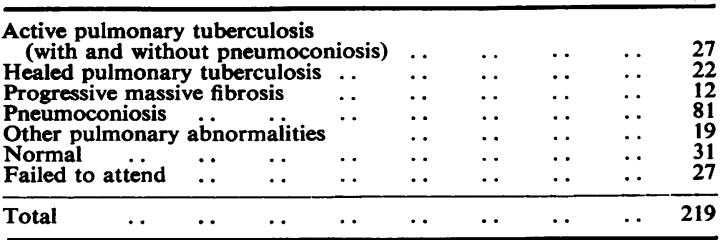

referred to the chest clinic for further assessment and diagnosis. It will be seen that 27 were considered to be suffering from active pulmonary tuberculosis. Table 4 shows the sub-division of these 27 cases by age, category of pneumoconiosis, and sputum state. All cases with pneumoconiosis, category 2 and above, were also offered interviews. Laryngeal swabs and sputum specimens were obtained from 166 working quarrymen including 10 cases of progressive massive fibrosis (P.M.F.). Table 4 gives the results of the

TABLE 4

RESULTS OF LARYNGEAL SWABS AND SPUTUM TESTS

\begin{tabular}{l|c|c|c|c|c}
\hline $\begin{array}{c}\text { Category } \\
\text { of } \\
\begin{array}{c}\text { Pneumo- } \\
\text { coniosis }\end{array}\end{array}$ & $\begin{array}{c}\text { No. of Cases } \\
\text { Swabbed } \\
\text { and/or Sputum } \\
\text { Tested }\end{array}$ & $\begin{array}{c}\text { No. of } \\
\text { Swabs } \\
\text { Taken }\end{array}$ & $\begin{array}{c}\text { No. of } \\
\text { Sputum } \\
\text { Tests } \\
\text { Obtained }\end{array}$ & $\begin{array}{c}\text { No. of } \\
\text { Laryngeal } \\
\text { Swabs } \\
\text { Positive }\end{array}$ & $\begin{array}{c}\text { No. of } \\
\text { Sputum } \\
\text { Tests } \\
\text { Positive }\end{array}$ \\
\hline Category 2 & 132 & 174 & 68 & 0 & 0 \\
Category 3 & 24 & 35 & 19 & 0 & 0 \\
P.M.F. & 10 & 16 & 6 & 1 & 1 \\
\hline Totals & 166 & 225 & 93 & 1 & 1 \\
\hline
\end{tabular}

laryngeal swabs and sputum tests carried out at the unit. Of the 10 men with P.M.F. who attended, one gave a positive sputum. Of 736 cases of P.M.F. among coal-miners and ex-coal-miners in the Rhondda Fach $1 \cdot 1 \%$ gave a positive sputum (Cochrane et al., 1952). The number of P.M.F. cases tested bacteriologically from the quarry workers is, however, too few for the difference to be statistically significant. None of the 156 cases of simple pneumoconiosis had a positive sputum.

It should be pointed out, however, that of the seven category 2 and 3 cases diagnosed at the clinic as suffering from active pulmonary tuberculosis, five had a positive sputum (Table 5). This would suggest that the laryngeal swabbing and sputum testing carried out on a single occasion at the unit were technically deficient as methods of discovering the tubercle bacillus when compared with similar tests carried out periodically at the chest clinic.

\section{Discussion}

Pneumoconiosis.-The figures for prevalence of pneumoconiosis amongst working quarrymen can 
TABLE 5

CASES DIAGNOSED AS ACTIVE PULMONARY TUBERCULOSIS AT THE CHEST CLINIC ANALYSED BY AGE, CATEGORY OF PNEUMOCONIOSIS, AND SPUTUM STATE

\begin{tabular}{|c|c|c|c|c|c|c|c|c|c|c|c|}
\hline \multirow{3}{*}{$\underset{\text { (years) }}{\text { Age }}$} & \multicolumn{10}{|c|}{ Category of Pneumoconiosis } & \multirow{3}{*}{ Total } \\
\hline & \multicolumn{2}{|c|}{$\mathbf{0}$} & \multicolumn{2}{|c|}{1} & \multicolumn{2}{|c|}{2} & \multicolumn{2}{|c|}{3} & \multicolumn{2}{|c|}{ P.M.F. } & \\
\hline & Sputum + & Sputum - & Sputum + & Sputum - & Sputum + & Sputum - & Sputum + & Sputum - & Sputum + & Sputum - & \\
\hline $\begin{array}{l}25-34 \\
35-44 \\
45-54 \\
55-64 \\
65+\end{array}$ & $\begin{array}{l}1 \\
1 \\
1 \\
1 \\
-\end{array}$ & $\begin{array}{l}1 \\
1 \\
1 \\
3 \\
1\end{array}$ & $\begin{array}{l}1 \\
1 \\
\overline{1}\end{array}$ & $\begin{array}{l}\frac{1}{4} \\
- \\
-\end{array}$ & $\begin{array}{l}- \\
\overline{2} \\
1 \\
1\end{array}$ & $\begin{array}{l}\overline{-} \\
\overline{1} \\
1 \\
-\end{array}$ & $\begin{array}{l}- \\
\overline{1} \\
-\end{array}$ & $\begin{array}{l}- \\
\bar{z} \\
-\end{array}$ & $\begin{array}{l}\overline{-} \\
\overline{1} \\
-\end{array}$ & $\begin{array}{l}- \\
\bar{z} \\
-\end{array}$ & $\begin{array}{l}4 \\
3 \\
9 \\
8 \\
3\end{array}$ \\
\hline Totals & 4 & 7 & 3 & 5 & 4 & 2 & 1 & - & 1 & - & 27 \\
\hline
\end{tabular}

be compared with those for the 6,026 miners and ex-miners in the Rhondda Fach radiological survey (Cochrane et al., 1952). The total prevalence of pneumoconiosis, especially if cases of category 1 are excluded, is much lower amongst working quarrymen than amongst miners and ex-miners in the Rhondda Fach. It should be noted here, however, that the difference in prevalence between quarry workers and miners might not have been so marked had ex-quarry workers been included in the survey. The total prevalence of pneumoconiosis of categories 2 and 3 was 83.5 per 1,000 examined amongst working quarrymen. In the Rhondda Fach, for 6,026 miners and ex-miners, the prevalence of similar cases was about 300 per 1,000 examined. The prevalence of pneumoconiosis is, therefore, much lower amongst the working quarrymen than amongst miners and ex-miners in the Rhondda Fach.

Tuberculosis.-With the reservation that 27 of the 213 cases of suspected pulmonary tuberculosis failed to attend the chest clinic, the prevalence of pulmonary tuberculosis amongst working quarrymen can be compared with that of the Rhondda Fach survey in certain particulars. Infectious tuberculosis amongst working quarrymen can be compared with that amongst surface and underground workers in four Rhondda Fach collieries (Cochrane et al., 1952). In 2,911 surface and underground coalminers, four cases of infectious tuberculosis were discovered, a rate of $1 \cdot 4$ per 1,000 . The rate of sputum-positive cases in working quarrymen was at least $5 \cdot 3$ per 1,000 .

It would appear, therefore, that in working quarrymen, although the total prevalence of pneumoconiosis and its radiological severity are lower than in miners and ex-miners, the prevalence of active pulmonary tuberculosis is higher. The rate for active tuberculosis in working quarrymen is $11 \cdot 1$ per 1,000, that for miners and ex-miners being $7 \cdot 5$ per 1,000 Table 3. Such a finding is consistent with the view that silica dust, when inhaled, decreases the resistance to tuberculosis (Vorwald and Delahant, 1938).
The incidence of tuberculosis amongst working quarrymen is also higher than that found in any other industry in routine surveys carried out by the Welsh Mass Radiography Service.

\section{PART II: SURVEY OF QUARRYING COMMUNITIES}

To establish the prevalence of pulmonary tuberculosis amongst ex-quarry workers and males not engaged in quarrying living in the quarrying towns and villages, it was necessary to carry out " total community" surveys of the Rhondda Fach type (Cochrane et al., 1952). Three population areas were selected in the largest of the quarrying communities within the Gwyrfai Rural District, viz., Llanberis, Deiniolen, and Pen-y-Groes. Many quarry workers live in smaller communities scattered on the mountain sides, but it was considered that the three population centres chosen would give the information required and would lend themselves well to the " total community" technique.

\section{Definition of the Three Communities Surveyed}

Arbitrary decisions were taken when defining the geographical extent and limits of the populations to be surveyed. This is unavoidable and indeed imperative in work of this kind. In doing so, we were mainly influenced by such factors as topography and the general concentration and distribution of the population. The population (including sex, age, and principal occupation) of the arbitrarily and geographically defined communities was ascertained by a census undertaken by the staff of the unit concerned in the actual radiography. Our figures do not, therefore, agree with any official rural or urban district population.

\section{Results}

Table $6 \mathrm{a}$ shows the response obtained in the three towns and Table $6 \mathrm{~b}$ analyses this response according to age, sex, and occupation.

The figures in these tables show the response obtained from the various sections of the three communities. Whilst not as satisfactory as the $90 \%$ 
TABLE 6a

ANALYSIS OF RESPONSE TO MASS RADIOGRAPHY SURVEYS IN THREE QUARRYING TOWNS

\begin{tabular}{|c|c|c|c|c|}
\hline & Llanberis & Deiniolen & Pen-y-Groes & Total \\
\hline $\begin{array}{l}\text { Population } \\
\text { Number radiographed } \\
\text { Number failing to attend } \\
\text { Percentage of popula- } \\
\text { tion radiographed }\end{array}$ & $\begin{array}{r}1,883 \\
1,437 \\
446 \\
76 \cdot 31\end{array}$ & $\begin{array}{r}1,251 \\
978 \\
273 \\
78 \cdot 18\end{array}$ & $\begin{array}{r}1,612 \\
1,158 \\
454 \\
71 \cdot 84\end{array}$ & $\begin{array}{l}4,746 \\
3,573 \\
1,173 \\
75.28\end{array}$ \\
\hline
\end{tabular}

TABLE 6b

ANALYSIS OF RESPONSE TO MASS RADIOGRAPHY IN THREE QUARRYING TOWNS ACCORDING TO AGE, SEX, AND PRINCIPAL OCCUPATIONAL GROUP

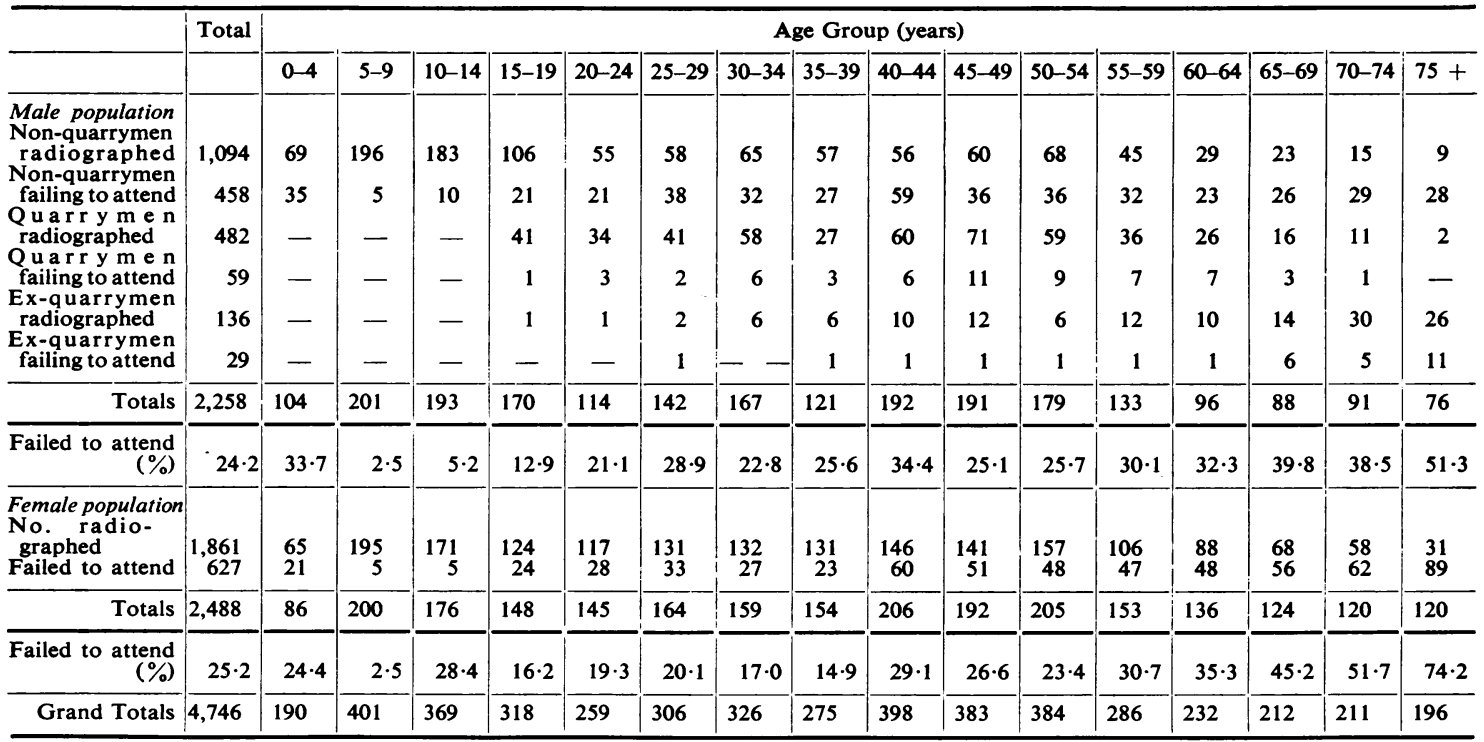

response obtained in the Rhondda Fach, the response was high enough for comparison to be made with the findings of the Rhondda survey (Cochrane et al., 1952), subject to certain reservations.

Prevalence of Pulmonary Tuberculosis.-To attempt an assessment of the prevalence of active pulmonary tuberculosis, a list was obtained from the chest clinic of those still on the "live" register of tuberculous persons living in the populations previously described and still considered to be suffering from active pulmonary tuberculosis. This list was checked with those kept by the County Medical Officer, and to it were added those persons found to be suffering from active tuberculosis as a result of the quarry survey who lived in the defined area, and those found to be suffering from active tuberculosis during the total community surveys who were not previously known. All these are included in those radiographed in Tables $6 \mathrm{a}$ and $6 \mathrm{~b}$.

The prevalence of pulmonary tuberculosis amongst those not radiographed is likely to be at least as great, if not greater, than amongst those radiographed, and it is for this reason that the prevalence rates are based on the number of persons radiographed and not on the total population figures for the three communities. These rates are, therefore, comparable with those found for active cases in the Rhondda Fach survey. Fig. 1 and Table 7 show the prevalence of active pulmonary tuberculosis (including infectious) by age, sex, and occupation for the three quarrying communities.

Comparison with the Rhondda Fach Survey.-The findings for prevalence of infectious and active pulmonary tuberculosis in certain groups compared with findings for similar groups in the Rhondda Fach are of interest.

Quarrymen and Ex-quarrymen.-Six hundred and eighteen quarry and ex-quarry workers were radiographed and 11 infectious and 26 non-infectious cases of active pulmonary tuberculosis were discovered. 


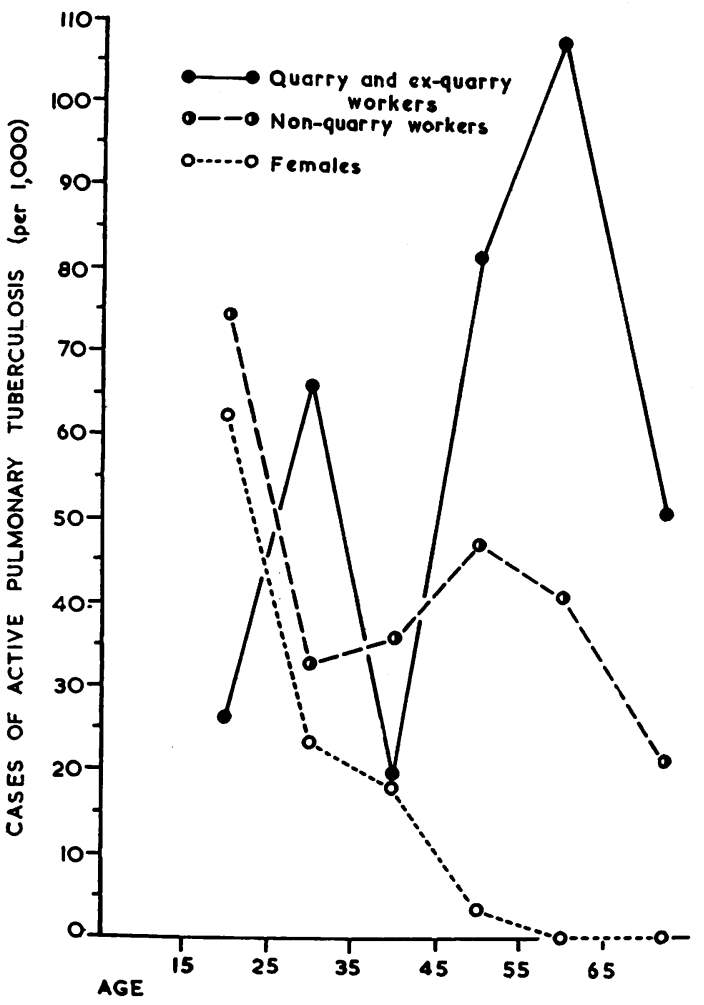

Fig. 1.-Prevalence of active pulmonary tuberculosis (including infectious) by age, sex, and occupation in three " quarrying" communities (or towns)

This gives a rate of $17 \cdot 8$ infectious cases per 1,000 radiographed, as compared with $5 \cdot 3$ per 1,000 amongst miners and ex-miners radiographed in the Rhondda Fach, and a rate of 60 per 1,000 for all active cases in this group as compared with
$7 \cdot 5$ per 1,000 for the Rhondda Fach (Fig. 2 and Tables 7 and 8).

Men not Engaged in Quarrying.-Amongst 646 non-slate male workers over the age of 15 radiographed in the three towns in the Gwyrfai Rural District, there were nine infectious and 21 noninfectious cases of pulmonary tuberculosis - a rate of 46.4 active cases per 1,000 radiographed compared with 13.5 per 1,000 for non-mining males in the same age group in the Rhondda Fach (Figs. 3 and 4, and Tables 7 and 8).

Females.-Amongst 1,430 females over the age of 15 radiographed in the three towns in the Gwyrfai Rural District, there were two infectious and 25 non-infectious cases of active pulmonary tuberculosis, a prevalence rate of 18.9 per 1,000 radiographed for all active cases as compared with 10.7 per 1,000 radiographed in the Rhondda Fach (Fig. 5 and Table 7).

Pneumoconiosis.-The purpose of the community survey was, primarily, to ascertain the prevalence of active pulmonary tuberculosis in the population of the three towns by age, sex, and principal occupation. The findings relative to pneumoconiosis are of less interest except perhaps where progressive massive fibrosis is concerned.

- Amongst the 618 quarry and ex-quarry workers radiographed there were 123 cases of pneumoconiosis of category 2 and over, including 65 cases of P.M.F. (Table 9), a rate for P.M.F. of 105 per 1,000 compared with 129 per 1,000 in the Rhondda Fach.

All of these P.M.F. cases were asked to attend for an interview but less than half came. Laryngeal swabs were taken and sputum specimens obtained

TABLE 7

PREVALENCE OF ACTIVE (INCLUDING INFECTIOUS) CASES OF PULMONARY TUBERCULOSIS IN THREE QUARRYING TOWNS BY AGE, SEX, AND OCCUPATION

\begin{tabular}{|c|c|c|c|c|c|c|c|c|c|c|c|c|c|}
\hline \multirow{3}{*}{ Age Group } & \multirow{2}{*}{$\begin{array}{c}\text { Total } \\
\text { Population } \\
\text { Radio- } \\
\text { graphed }\end{array}$} & \multicolumn{4}{|c|}{ Females } & \multicolumn{4}{|c|}{$\begin{array}{l}\text { Male Quarry and Ex-quarry } \\
\text { Workers }\end{array}$} & \multicolumn{4}{|c|}{ Male Non-quarry Workers } \\
\hline & & $\begin{array}{l}\text { Number } \\
\text { Radio-- } \\
\text { graphed }\end{array}$ & \multicolumn{2}{|c|}{$\begin{array}{l}\text { Number of } \\
\text { Active Cases }\end{array}$} & \multirow{3}{*}{ 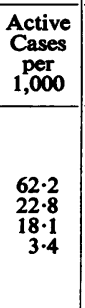 } & \multirow{3}{*}{$\begin{array}{c}\begin{array}{c}\text { Number } \\
\text { Radio- } \\
\text { graphed }\end{array} \\
\\
\\
77 \\
107 \\
103 \\
148 \\
84 \\
99\end{array}$} & \multicolumn{2}{|c|}{$\begin{array}{l}\text { Number of } \\
\text { Active Cases }\end{array}$} & \multirow{3}{*}{$\begin{array}{c}\begin{array}{c}\text { Active } \\
\text { Cases } \\
\text { per } \\
1,000\end{array} \\
\\
\\
\\
26 \cdot 0 \\
65 \cdot 4 \\
19 \cdot 4 \\
81 \cdot 1 \\
107 \cdot 1 \\
50 \cdot 5\end{array}$} & \multirow{3}{*}{$\begin{array}{c}\begin{array}{c}\text { Number } \\
\text { Radio- } \\
\text { graphed }\end{array} \\
\\
\\
161 \\
123 \\
113 \\
128 \\
74 \\
47\end{array}$} & \multicolumn{2}{|c|}{$\begin{array}{l}\text { Number of } \\
\text { Active Cases }\end{array}$} & \multirow[t]{2}{*}{$\begin{array}{c}\text { Active } \\
\text { Cases } \\
\text { per } \\
1,000\end{array}$} \\
\hline & & & $\begin{array}{c}\text { Sputum } \\
+ \text { ve }\end{array}$ & $\underset{-v e}{\text { Sputum }}$ & & & $\begin{array}{c}\text { Sputum } \\
\text { +ve }\end{array}$ & $\begin{array}{c}\text { Sputum } \\
- \text { ve }\end{array}$ & & & $\begin{array}{c}\text { Sputum } \\
+ \text { ve }\end{array}$ & $\underset{-v e}{\text { Sputum }}$ & \\
\hline $\begin{array}{l}15-24 \\
25-34 \\
35-44 \\
45-54 \\
55-64 \\
65+\end{array}$ & $\begin{array}{l}479 \\
493 \\
493 \\
574 \\
352 \\
303\end{array}$ & $\begin{array}{l}241 \\
263 \\
277 \\
298 \\
194 \\
157\end{array}$ & 2 & $\begin{array}{r}13 \\
6 \\
5 \\
1\end{array}$ & & & $\begin{array}{l}2 \\
2 \\
1 \\
4 \\
2\end{array}$ & $\begin{array}{r}5 \\
1 \\
12 \\
5 \\
3\end{array}$ & & & $\begin{array}{l}3 \\
1 \\
3 \\
2\end{array}$ & $\begin{array}{l}9 \\
\mathbf{4} \\
\mathbf{3} \\
\mathbf{3} \\
\mathbf{1} \\
\mathbf{1}\end{array}$ & $\begin{array}{l}74 \cdot 5 \\
32 \cdot 5 \\
35 \cdot 4 \\
46.9 \\
40 \cdot 5 \\
21 \cdot 3\end{array}$ \\
\hline \multirow[t]{2}{*}{$0-15$} & $\begin{array}{r}2,694 \\
879\end{array}$ & $\begin{array}{r}1,430 \\
431\end{array}$ & 2 & $\begin{array}{r}25 \\
1\end{array}$ & $\begin{array}{r}18 \cdot 9 \\
2 \cdot 3\end{array}$ & 618 & 11 & 26 & $59 \cdot 9$ & $\begin{array}{l}646 \\
448\end{array}$ & 9 & $\begin{array}{r}21 \\
7\end{array}$ & $\begin{array}{l}46 \cdot 4 \\
15 \cdot 6\end{array}$ \\
\hline & 3,573 & 1,861 & 2 & 26 & $15 \cdot 1$ & 618 & 11 & 26 & 59.9 & 1,094 & 9 & 28 & 33.8 \\
\hline
\end{tabular}


TABLE 8

PREVALENCE OF INFECTIOUS PULMONARY TUBERCULOSIS IN MALES IN THREE QUARRYING TOWNS BY AGE AND OCCUPATION

\begin{tabular}{|c|c|c|c|c|c|c|c|c|c|}
\hline \multirow[b]{2}{*}{$\begin{array}{l}\text { Age Group } \\
\text { (years) }\end{array}$} & \multicolumn{3}{|c|}{ Quarry and Ex-quarry Workers } & \multicolumn{3}{|c|}{ Non-quarry Workers } & \multicolumn{3}{|c|}{ Total Males } \\
\hline & $\begin{array}{l}\text { Number } \\
\text { Radio- } \\
\text { graphed }\end{array}$ & $\begin{array}{l}\text { Number of } \\
\text { Infectious } \\
\text { Cases }\end{array}$ & $\begin{array}{c}\text { Infectious } \\
\text { Cases per } \\
1,000\end{array}$ & $\begin{array}{c}\text { Number } \\
\text { Radio- } \\
\text { graphed }\end{array}$ & $\begin{array}{l}\text { Number of } \\
\text { Infectious } \\
\text { Cases }\end{array}$ & $\begin{array}{c}\text { Infectious } \\
\text { Cases per } \\
1,000\end{array}$ & $\begin{array}{c}\text { Number } \\
\text { Radio- } \\
\text { graphed }\end{array}$ & $\begin{array}{l}\text { Number of } \\
\text { Infectious } \\
\text { Cases }\end{array}$ & $\begin{array}{c}\text { Infectious } \\
\text { Cases per } \\
1,000\end{array}$ \\
\hline \multirow[t]{2}{*}{$\begin{array}{l}15-24 \\
25-34 \\
35-44 \\
45-54 \\
55-64 \\
65+\end{array}$} & $\begin{array}{r}77 \\
107 \\
103 \\
148 \\
84 \\
99\end{array}$ & $\begin{array}{l}2 \\
2 \\
1 \\
4 \\
2\end{array}$ & $\begin{array}{c}26 \cdot 0 \\
18 \cdot 7 \\
9 \cdot 7 \\
\overline{47 \cdot 6} \\
20 \cdot 2\end{array}$ & $\begin{array}{r}161 \\
123 \\
113 \\
128 \\
74 \\
47\end{array}$ & $\begin{array}{l}3 \\
1 \\
3 \\
2 \\
-\end{array}$ & $\begin{array}{c}18 \cdot 6 \\
\overline{8 \cdot 9} \\
23 \cdot 4 \\
27 \cdot 0 \\
-\end{array}$ & $\begin{array}{l}238 \\
230 \\
216 \\
276 \\
158 \\
146\end{array}$ & $\begin{array}{l}5 \\
2 \\
2 \\
3 \\
6 \\
2\end{array}$ & $\begin{array}{r}21 \cdot 0 \\
8 \cdot 7 \\
9 \cdot 3 \\
10 \cdot 9 \\
38 \cdot 0 \\
13 \cdot 7\end{array}$ \\
\hline & 618 & 11 & $17 \cdot 8$ & 646 & 9 & $13 \cdot 9$ & 1,264 & 20 & $15 \cdot 8$ \\
\hline
\end{tabular}

from the 28 who attended, and in no case was a positive result obtained. The number of cases tested is, unfortunately, too small to justify drawing any conclusions as to the infectivity of P.M.F. cases discovered in the survey. It should be noted, however, that of the 37 cases diagnosed at the clinic as suffering from active pulmonary tuberculosis from amongst the $\mathbf{6 1 8}$ quarry and ex-quarry workers, 29 had pneumoconiosis of category 2 or over, and eight of these had a positive sputum, including three cases of P.M.F. in ex-quarrymen. This adds weight to the contention made earlier in this paper that laryngeal swabbing and sputum testing done on a single occasion in the field are not sufficiently effective methods of detecting the tubercle bacillus (Table 10).

\section{Discussion}

The prevalence rates for both infectious and total active cases of pulmonary tuberculosis amongst males in the quarrying communities are considerably higher than those found in the Rhondda Fach survey. The prevalence rate for P.M.F. is rather lower in the quarrying community.

In assessing the significance of these findings account has to be taken of certain differences between the two surveys. In the survey of quarrying communities small films were used; there was a higher rate of failure to attend and perhaps a less intensive search for the tubercle bacillus was made in doubtful cases than was possible in the research project in the Rhondda. All these differences tended to minimize the rates for active and infectious cases in the quarrying community. Thus it is highly probable that the true differences are really greater than indicated by the figures in this paper.

There is also the difficulty of separating P.M.F. from tuberculosis and deciding on the degree of activity from the radiograph. This is even more difficult in the type of film seen among the quarrymen

FIG. 2.-Prevalence of infectious pulmonary tuberculosis in quarry and ex-quarry workers compared with miners and ex-miners in a coal-mining valley.

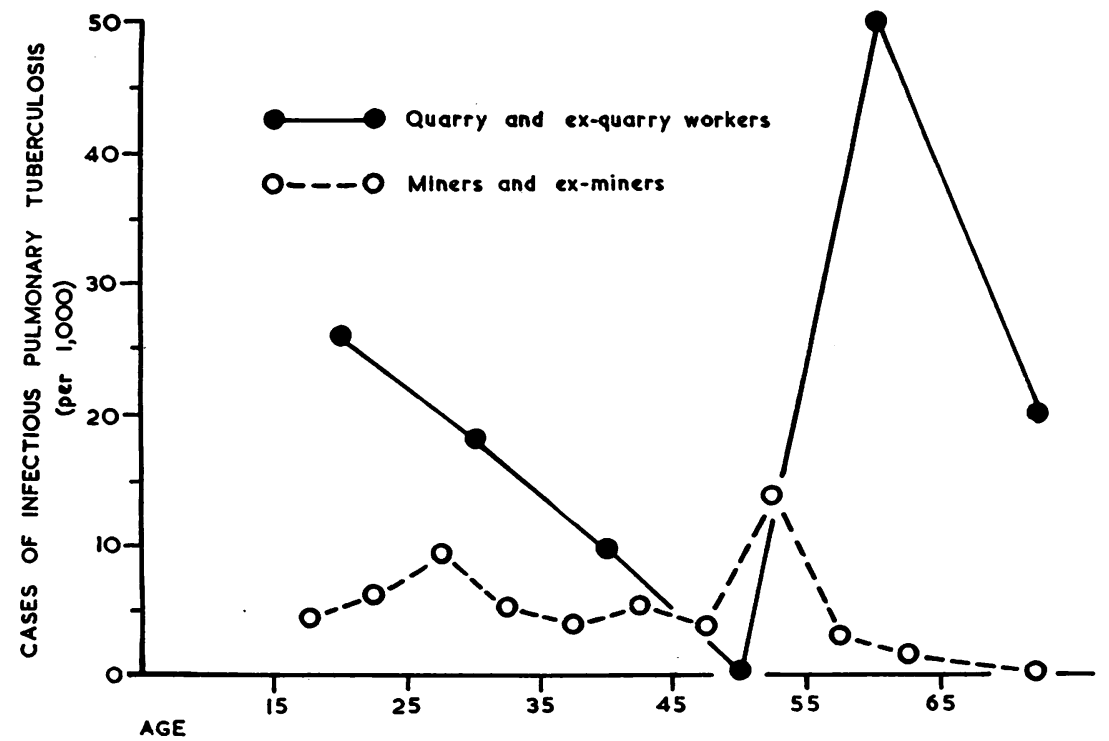




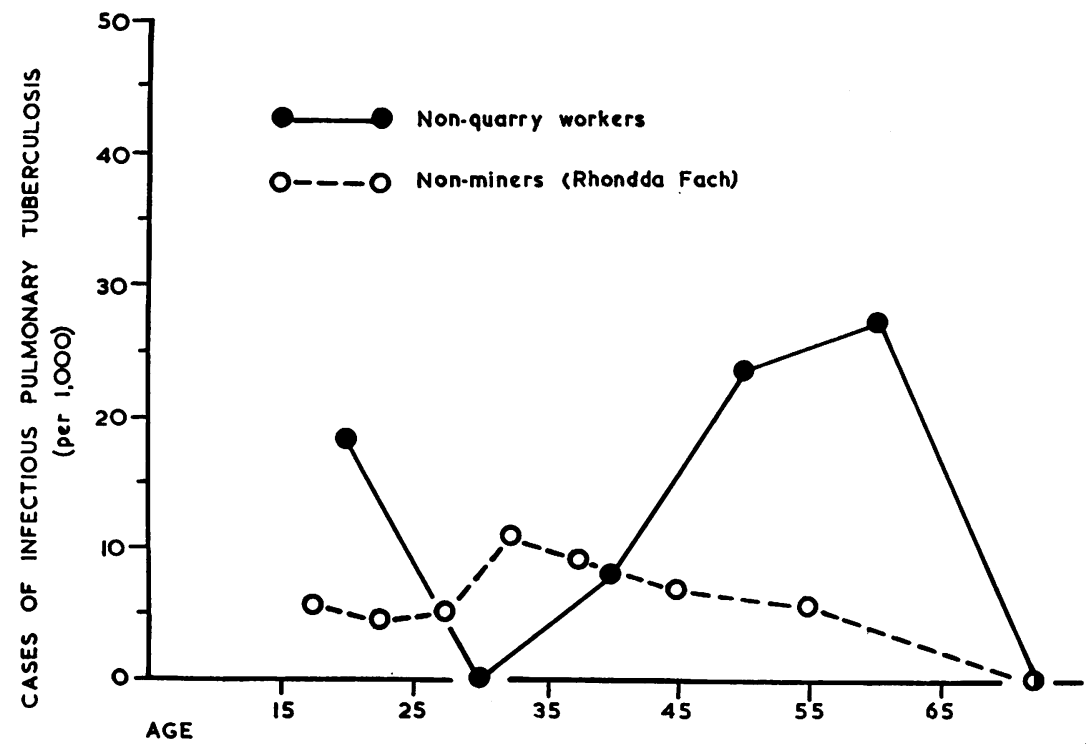

Fig. 3.-Prevalence of infectious pulmonary tuberculosis in workers not engaged in quarrying compared with that in non-miners in a coal-mining valley.

than in the miners. When a composite rate for infectious and non-infectious pulmonary tuberculosis and P.M.F. is calculated (Table 11) the rate for the quarrying community $(165$ per 1,000$)$ is again higher than that for the mining community (136 per 1,000 ).

It is somewhat surprising and of considerable interest and importance that the prevalence of active cases amongst the males not engaged in quarrying should be so high when compared with the Rhondda Fach (Tables 7 and 11). This makes it almost impossible to answer with certainty the question, Is the quarrying industry responsible for the high prevalence rates for active cases of pulmonary tuberculosis in the Gwyrfai district ? It may be that the pneumoconiosis of quarry workers increases their risk so far as pulmonary tuberculosis is concerned, but this has not been proved by this survey. Nevertheless, the very high prevalence rate of 60 active cases per 1,000 examined amongst the quarry and ex-quarry workers does suggest that their occupation is an important factor in determining

Fig. 4.-Prevalence of infectious pulmonary tuberculosis in all workers in three quarrying towns compared with that in all workers in a coal-mining valley.

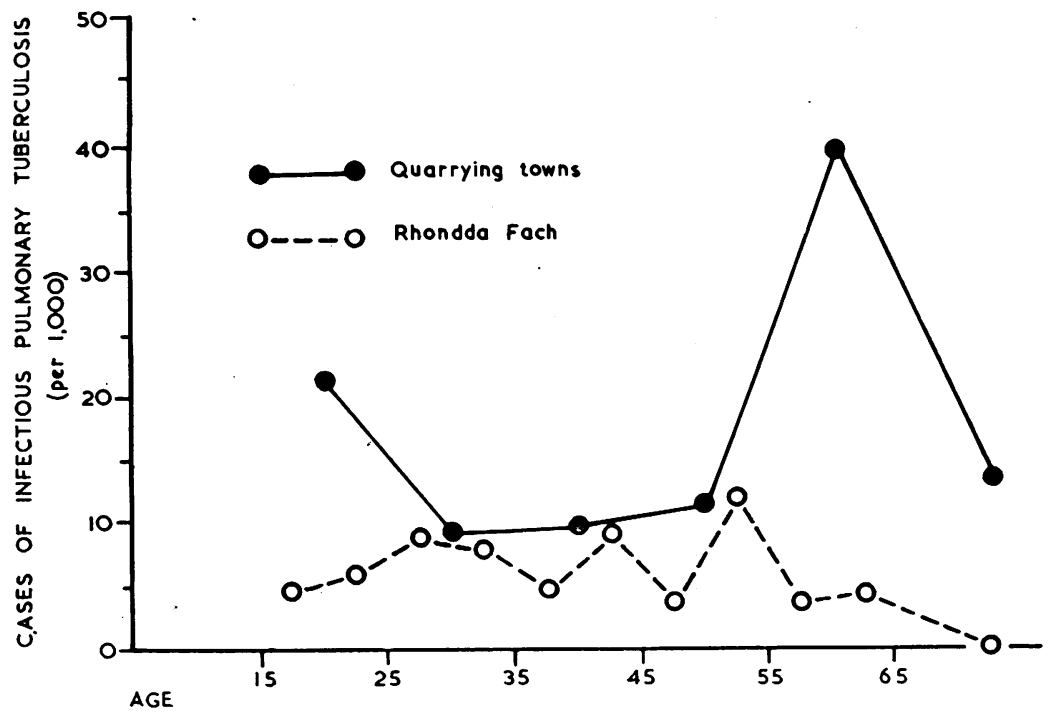




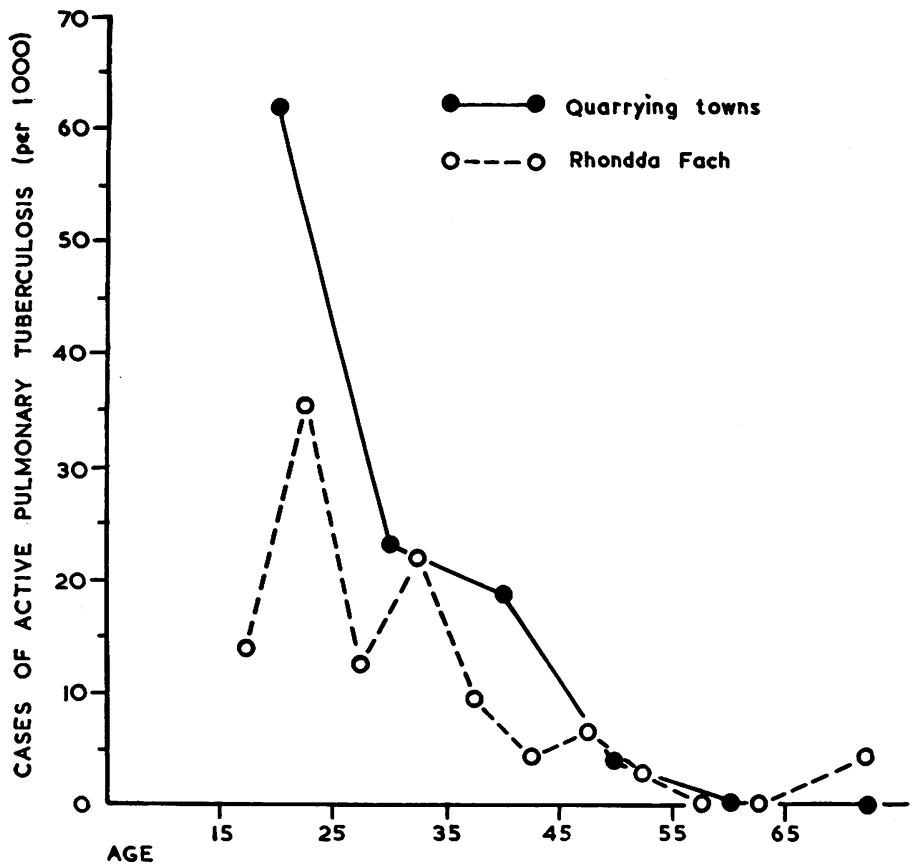

Fig. 5.-Prevalence of active pulmonary tuberculosis (including infectious) in females in three quarrying towns compared with that in females living in a coal-mining valley.

this rate. The prevalence for all infectious cases of at least 18 per 1,000 examined suggests that this may be an important source of infection for the male population, especially when the gregarious habits of the older age groups of this section of the community are taken into account. It is clear, also, that the male population of the quarrying communities is, as a whole, at special risk so far as pulmonary tuberculosis is concerned. The female population is, however (except for the age group 15-25), at only slightly greater risk than that in the Rhondda Fach.

TABLE 9

PNEUMOCONIOSIS IN 618 QUARRY AND EX-QUARRY WORKERS IN THREE QUARRYING TOWNS

\begin{tabular}{|c|c|c|c|c|c|c|c|c|c|c|c|}
\hline \multirow{3}{*}{$\begin{array}{c}\text { Age } \\
\text { Groups } \\
\text { (years) }\end{array}$} & \multicolumn{10}{|c|}{ Category of Pneumoconiosis } & \multirow{2}{*}{ Total } \\
\hline & \multicolumn{2}{|c|}{0} & \multicolumn{2}{|c|}{1} & \multicolumn{2}{|c|}{2} & \multicolumn{2}{|c|}{3} & \multicolumn{2}{|c|}{ P.M.F. } & \\
\hline & $\begin{array}{c}\text { Quarry } \\
\text { Workers }\end{array}$ & $\begin{array}{c}\text { Ex-quarry } \\
\text { Workers }\end{array}$ & $\begin{array}{l}\text { Quarry } \\
\text { Workers }\end{array}$ & $\begin{array}{l}\text { Ex-quarry } \\
\text { Workers }\end{array}$ & $\begin{array}{c}\text { Quarry } \\
\text { Workers }\end{array}$ & $\begin{array}{c}\text { Ex-quarry } \\
\text { Workers }\end{array}$ & $\begin{array}{l}\text { Quarry } \\
\text { Workers }\end{array}$ & $\begin{array}{c}\text { Ex-quarry } \\
\text { Workers }\end{array}$ & $\begin{array}{l}\text { Quarry } \\
\text { Workers }\end{array}$ & $\begin{array}{c}\text { Ex-quarry } \\
\text { Workers }\end{array}$ & \\
\hline $\begin{array}{l}15-24 \\
25-34 \\
35-44 \\
45-54 \\
55-64 \\
65+\end{array}$ & $\begin{array}{r}75 \\
98 \\
79 \\
105 \\
32 \\
17\end{array}$ & $\begin{array}{r}2 \\
8 \\
13 \\
12 \\
12 \\
25\end{array}$ & $\begin{array}{l}1 \\
1 \\
6 \\
6 \\
1\end{array}$ & $\begin{array}{l}\bar{z} \\
\bar{z}\end{array}$ & $\begin{array}{c}- \\
6 \\
9 \\
8 \\
3\end{array}$ & $\begin{array}{c}\bar{Z} \\
2 \\
2 \\
2 \\
1\end{array}$ & $\begin{array}{c}\bar{Z} \\
3 \\
5 \\
1\end{array}$ & $\bar{z}$ & $\begin{array}{r}7 \\
1 \\
7 \\
11 \\
7\end{array}$ & $\begin{array}{r}\overline{7} \\
1 \\
2 \\
31\end{array}$ & $\begin{array}{r}77 \\
107 \\
103 \\
148 \\
84 \\
99\end{array}$ \\
\hline \multirow[b]{2}{*}{ Totals } & 406 & 72 & 15 & 2 & 26 & 7 & 9 & 16 & 26 & 39 & \\
\hline & \multicolumn{2}{|c|}{478} & \multicolumn{2}{|c|}{17} & \multicolumn{2}{|c|}{33} & \multicolumn{2}{|c|}{25} & \multicolumn{2}{|c|}{65} & 618 \\
\hline
\end{tabular}

TABLE 10

ANALYSIS OF 37 CASES OF ACTIVE PULMONARY TUBERCULOSIS IN 618 QUARRY AND EX-QUARRY WORKERS BY CATEGORY OF PNEUMOCONIOSIS AND SPUTUM STATE

\begin{tabular}{|c|c|c|c|c|c|c|c|c|c|c|c|}
\hline \multirow{3}{*}{$\begin{array}{c}\text { Age } \\
\text { (years) }\end{array}$} & \multicolumn{10}{|c|}{ Category of Pneumoconiosis } & \multirow{2}{*}{ Total } \\
\hline & \multicolumn{2}{|c|}{0} & \multicolumn{2}{|c|}{1} & \multicolumn{2}{|c|}{2} & \multicolumn{2}{|c|}{3} & \multicolumn{2}{|c|}{ P.M.F. } & \\
\hline & $\begin{array}{c}\text { Sputum } \\
+ \text { ve }\end{array}$ & $\underset{\text { Sputum }}{\text { Spe }}$ & $\begin{array}{c}\text { Sputum } \\
\text { +ve }\end{array}$ & $\begin{array}{c}\text { Sputum } \\
\text {-ve }\end{array}$ & $\begin{array}{c}\text { Sputum } \\
\text { + ve }\end{array}$ & $\begin{array}{c}\text { Sputum } \\
\text {-ve }\end{array}$ & $\begin{array}{c}\text { Sputum } \\
+ \text { ve }\end{array}$ & $\underset{- \text { ve }}{\text { Sputum }}$ & $\begin{array}{c}\text { Sputum } \\
+ \text { ve }\end{array}$ & $\begin{array}{c}\text { Sputum } \\
\text {-ve }\end{array}$ & \\
\hline $\begin{array}{l}15-24 \\
25-34 \\
35-44 \\
45-54 * \\
55-64 \\
65+\end{array}$ & $\begin{array}{l}2 \\
1 \\
= \\
= \\
-\end{array}$ & $\begin{array}{l}\overline{4} \\
\overline{1} \\
\overline{-}\end{array}$ & $\begin{array}{l}\overline{-} \\
\bar{z} \\
\bar{z} \\
\bar{z}\end{array}$ & $\begin{array}{l}\bar{z} \\
\bar{z} \\
\bar{z}\end{array}$ & $\begin{array}{l}\overline{1} \\
\overline{2} \\
-\end{array}$ & $\begin{array}{l}\overline{1} \\
1 \\
6 \\
4 \\
2\end{array}$ & $\begin{array}{l}\overline{-} \\
\overline{1} \\
\frac{1}{1}\end{array}$ & $\begin{array}{l}\overline{-} \\
\overline{5} \\
1 \\
1\end{array}$ & $\begin{array}{l}\overline{-} \\
\bar{z} \\
\overline{1} \\
2\end{array}$ & $\begin{array}{l}\bar{z} \\
\bar{z} \\
\bar{z}\end{array}$ & $\begin{array}{r}2 \\
7 \\
2 \\
12 \\
9 \\
5\end{array}$ \\
\hline Totals & 3 & 5 & - & - & 3 & 14 & 2 & 7 & 3 & - & 37 \\
\hline
\end{tabular}

* Of the 12 cases in age group 45-54 who were originally sputum negative, six became sputum positive after January, 1955. This would alter Fig. 2 as the prevalence of infectious pulmonary tuberculosis in quarry and ex-quarry workers would be much higher at all ages than in miners and ex-miners. 
TABLE 11

COMPARISON OF PREVALENCE OF TUBERCULOSIS AND COMPLICATED PNEUMOCONIOSIS AMONG QUARRYMEN AND EX-QUARRYMEN AND MINERS AND EX-MINERS

\begin{tabular}{|c|c|c|c|c|c|c|}
\hline Groups & Radiographed & $\begin{array}{c}\text { (1) } \\
\text { Infectious } \\
\text { Tuberculosis }\end{array}$ & $\begin{array}{l}\text { (2) } \\
\text { Non-infectious } \\
\text { Tuberculosis }\end{array}$ & P.M.F. & (1), & $\begin{array}{l}\text { tal } \\
\text { 2), (3) }\end{array}$ \\
\hline $\begin{array}{l}\text { Quarrymen and ex-quarrymen } \\
\text { Miners and ex-miners } \\
\text { (Rhondda Fach, 1951) }\end{array}$ & $\begin{array}{r}618 \\
6,026\end{array}$ & $\begin{array}{ll}11 & (17 \cdot 8)^{*} \\
32 & (5 \cdot 3)\end{array}$ & $\begin{array}{rr}26 & (42 \cdot 1) \\
13 & (2 \cdot 2)\end{array}$ & $\begin{array}{rr}65 & (105 \cdot 2) \\
776 & (128 \cdot 8)\end{array}$ & $\begin{array}{l}102 \\
821\end{array}$ & $\begin{array}{l}(165) \\
(136)\end{array}$ \\
\hline
\end{tabular}

* Figures in parentheses indicate rates per 1,000 examined.

\section{SUMMARY}

Part I

Two thousand four hundred and thirty-two working quarrymen from five slate quarries in Caernarvonshire were radiographed using $70 \mathrm{~mm}$. films. This represents $90 \%$ of all the workers at these quarries.

The prevalence of pneumoconiosis of category 2 and upwards was 83 per 1,000 examined amongst working quarrymen; in the Rhondda Fach the rate for miners and ex-miners was about 300 per 1,000 examined.

The prevalence of infectious tuberculosis amongst the working quarrymen examined was $5 \cdot 3$ per 1,000 examined in contrast to the lower rate for working miners in the Rhondda Fach of 1.4 per 1,000 examined.

Active and infectious pulmonary tuberculosis is a more serious problem than simple pneumoconiosis in this group of the industry.

\section{Part II}

Seventy-five per cent. of the population of three slate-quarrying towns in the Gwyrfai Rural District of North Wales were radiographed. Prevalence rates for active pulmonary tuberculosis amongst quarry and ex-quarry workers, males not engaged in quarrying, and females, based on this survey and subsequent diagnostic follow-up at the chest clinic, are presented and comparisons made with findings in similar groups in the Rhondda Fach in South Wales.

The prevalence of infectious cases amongst quarry and ex-quarry workers was $17 \cdot 8$ per 1,000 radiographed as compared with $5 \cdot 3$ per 1,000 amongst miners and ex-miners in the Rhondda Fach, and a rate of 60 per 1,000 for all active cases (including infectious) in this group compared with $7 \cdot 5$ per 1,000 for the Rhondda Fach. The prevalence rate for all active cases of tuberculosis amongst males not engaged in quarrying was 46.4 per 1,000 radiographed compared with 13.5 per 1,000 for males not engaged in mining in the Rhondda Fach. The prevalence rate for active cases amongst females, over the age of 15 , was $18 \cdot 9$ per 1,000 radiographed compared with 10.7 per 1,000 in the Rhondda Fach.

It would appear that quarriers and males not engaged in quarrying living in quarrying communities are at considerably greater risk of contracting pulmonary tuberculosis than miners and males not engaged in mining in a coal-mining valley. Though it has not been definitely proved that the pneumoconiosis of quarry workers is responsible for this, the findings do suggest that working in the slate quarries may be an important contributory and perhaps a major determining factor.

Our thanks are due in the first place to the radiography teams who carried out enthusiastically duties which were by no means always those of a routine mass radiography nature; to Drs. J. C. Gilson, A. L. Cochrane, and W. E. Miall, of the Medical Research Council's Pneumoconiosis Research Unit, for very generous advice, criticism, and help in the preparation of this paper; to Dr. J. Marks, of the Central Tuberculosis Laboratory, Cardiff, for the bacteriological work; and to Mr. Fred Moore for the preparation of the graphs.

\section{REFERENCES}

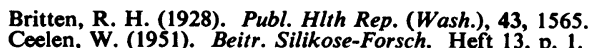

Chalke, H. D. (1933). Welsh National Memorial Special Report. Cardiff.

Cochrane, A. L., Cox, J. G., and Jarman, T. F. (1952). Brit. med. J., $2,843$.

Davies, I., and Fletcher, C. M. (1951). Brit. J. industr. Med., 8,

Davies, T. W. (1939). Tubercle (Lond.), $20,543$.

(1942). Publ. Hith (Lond.), 55, 101, 122

Feil, A. (1935). Bull. Accd. Méd. (Paris), 113, 105.

Fletcher, C. M., Mann, K. J., Davies, I., Cochrane, A. L., Gilson, J.C. and Hugh-Jones, P. (1949). J. Fac. Radiol, (Lond.), 1, 40.

Frola, E. (1942). Rass. Med. industr., 13, 284.

Koelsch, K. A. (1950). In Jötten, K. W., and Gärtner, H. Die Staublungenerkrankungen, p. 153. "Wissenschaftliche Forschungsberichte. Naturwissenschaftliche Reihe, Steinkopf, Darmstadt. Vol. 60.

Mansur, R. H. (1951). Amer. industr. Hyg. Ass. Quart., 12, 21.

Ministry of Works (1947). The Welsh Slate Industry. Report by a Committee (Chairman: Rees, F.). H.M.S.O., London.

Registrar-General (1927). Decennial Supplement. England and Wales, 1921. Part II. Occupational Mortality, Fertility and Infant Mortality. H.M.S.O., London.

Rogers, E. J. (1932). New Engl. J.' Med., 207, 203.

Schairer, E. (1940). Arch. Gewerbepath. Gewerbehyg., 10, 37.

Schairer, E. (1940). Arch. Gewerbepath. Gewerbehyg., 10, 37.
Sutherland, C. L., and Bryson, S. (1930). Mines Department. Report on an Inquiry into the Occurrence of Disease of the Lungs from Dust Inhalation in the Slate Industry in the Gwyrfai

District. H.M.S.O., London.
Vorwald, A. J., and Delahant, A. B. (1938). Amer. Rev. Tuberc., 38,

Wade, T. W. (1927). Ministry of Health. Welsh Board of Health. Reports on Public Health and Medical Subjects, No. 38. H.M.S.O., London.
H. 